\title{
Pengaruh Model Pembelajaran Student Facilitator and Explaining Terhadap Kemampuan Komunikasi Matematis Siswa Pada Materi SPLTV Kelas X MIPA
}

Sari Asih ${ }^{1}$, Resy Nirawati ${ }^{2}$, Nurhayati ${ }^{3}$

Program Studi Pendidikan Matematika, STKIP Singkawang, Singkawang, Indonesia

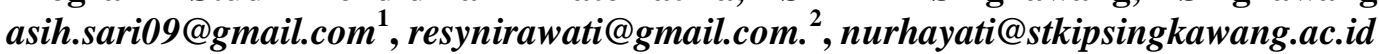

\begin{tabular}{|c|c|}
\hline $\begin{array}{lr}\text { Kata Kunci : } & \\
\text { Pembelajaran } & \text { Student } \\
\text { Facilitator and } & \text { Explaining, } \\
\text { Komunikasi, } & \text { Aktivitas, } \\
\text { Kemandirian Belajar, SPLTV. }\end{array}$ & $\begin{array}{l}\text { ABSTRAK } \\
\text { Penelitian ini bertujuan untuk mengetahui pengaruh model } \\
\text { pembelajaran Student Facilitator and Explaining terhadap } \\
\text { kemampuan komunikasi matematis siswa pada materi SPLTV. } \\
\text { Penelitian yang digunakan adalah penelitian kuantitatif } \\
\text { dengan bentuk penelitian Quasi Eksperimen dan desain } \\
\text { penelitian Posttest-Only Control Design. Populasi dalam } \\
\text { penelitian ini adalah siswa kelas X yang terdiri dari } 4 \text { kelas } \\
\text { dengan jumlah siswa sebanyak } 125 \text { orang. Sampel diambil } \\
\text { menggunakan purposive sampling dan terpilih kelas XMIPA } 2 \\
\text { yang berjumlah } 30 \text { siswa sebagai kelas eksperimen dan kelas X } \\
\text { MIPA } 4 \text { yang berjumlah } 30 \text { siswa sebagai kelas kontrol. } \\
\text { Pengambilan data menggunakan instrumen tes kemampuan } \\
\text { komunikasi matematis, lembar observasi aktivitas belajar } \\
\text { siswa dan angket kemandirian belajar siswa. Tes layak } \\
\text { digunakan karena telah melalui pengujian validitas, } \\
\text { reliabilitas sebesar } r_{11}=0,57, \text { daya pembeda dan indeks } \\
\text { kesukaran. Hasil analisis menunjukan bahwa terdapat } \\
\text { pengaruh kemampuan komunikasi matematis setelah diberikan } \\
\text { model pembelajaran Student Facilitator and Explaining } \\
\text { dengan diperoleh } t \text { hitung } \geq t \text { tabel }(5,69>1,671) \text {. Aktivitas belajar } \\
\text { siswa setelah diberikan model pembelajaran Student } \\
\text { Facilitator and Explaining memperoleh hasil rata-rata } \\
\text { persentase seluruh pertemuan sebesar } 81,25 \% \text { termasuk dalam } \\
\text { kriteria. Hasil rata }- \text { rata kemandirian belajar siswa dengan } \\
\text { model pembelajaran Student Facilitator and Explaining } \\
\text { sebesar } 44,73 \text { dengan kategoribaik. }\end{array}$ \\
\hline
\end{tabular}

\section{PENDAHULUAN}

Matematika adalah suatu ilmu pasti yang mendasari daya pikir, membantu serta memajukan manusia dalam kehidupan sehari-hari. Hal ini sependapat dengan Buyung \& Nirawati (2018: 21) bahwa matematika mempunyai arti penting dalam membantu manusia dalam meyelesaikan masalah pada kehidupan sehari-hari. Tujuan pembelajaran matematika yang dirumuskan Kurikulum Tingkat Satuan Pendidikan menyatakan bahwa mata pelajaran matematika bertujuan agar peserta didik mempunyai kemampuan untuk memahami konsep matematika, menggunakan penalaran, memecahkan masalah, mengkomunikasikan gagasan dengan simbol, tabel, diagram, atau media lain untuk memperjelas keadaan atau masalah serta memiliki sikap 
menghargai kegunaan matematika dalam kehidupan (BSNP, 2006). Oleh sebab itu untuk mencapai tujuan pembelajaran matematika, salah satu aspek yang harus dikuasai siswa adalah kemampuan komunikasi matematis.

Menurut Kusumah Y.S (Jazuli, 2009:215), menyatakan bahwa "komunikasi merupakan bagian yang sangat penting dalam pembelajaran matematika". Melalui komunikasi ide matematika dapat dieksploitasi dalam berbagai perspektif, cara berfikir siswa dapat dipertajam, pertumbuhan pemahaman dapat diukur, pemikiran siswa dapat dikonsolidasikan dan diorganisir, pengetahuan matematika dan pengembangan masalah siswa dapat ditingkatkan, dan komunikasi matematika dapat dibentuk. Menurut Asikin dalam Darkasyi (2014:26) komunikasi memiliki peranan penting dalam pembelajaran matematika yaitu melalui komunikasi, siswa dapat mengorganisasikan dan mengkondisikan pemikiran matematika yang dimilikinya. Pentingnya komunikasi matematis juga dikemukakan oleh Zainab (2011:4) yang menyatakan bahwa "komunikasi matematis sangat penting karena matematika tidak hanya menjadi alat berfikir yang membantu siswa untuk mengembangkan pola, menyelesaikan masalah dan menarik kesimpulan tetapi juga sebagai alat untuk mengkomunikasikan pikiran, ide dan gagasan secara jelas, tepat dan singkat". Mengingat pentingnya kemampuan komunikasi matematis tersebut seharusnya seorang guru dapat membangun kemampuan komunikasi matematis siswanya agar tujuan pembelajaran matematika bisa tercapai dengan baik.

Namun pada kenyataannya, berdasarkan hasil prariset mengenai kemampuan komunikasi matematis siswa di kelas X MIPA 4 SMA Negeri 1 Singkawang yang memuat 3 indikator kemampuan komunikasi matematis, yaitu (1) Ekspresi matematika/mathematical expression, Menggambar/drawing, (3) Menulis/written texts, kepada 30 siswa dan hasil kemampuan komunikasi matematis siswa sangat rendah untuk 3 indikator komunikasi tersebut. Dari hasil pekerjaan siswa diketahui bahwa siswa tidak memahami masalah yang diberikan, dapat dilihat dari hasil pekerjaan siswa. (Soal terlampir)

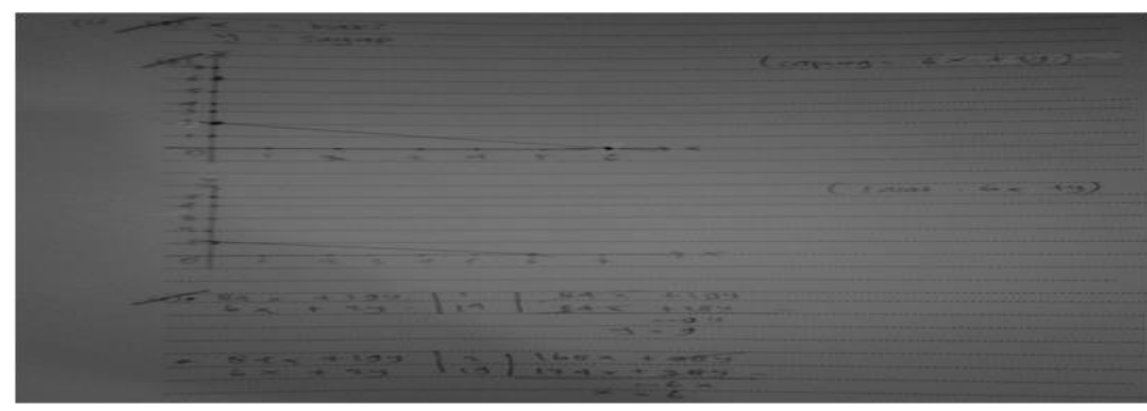

Gambar 1. Hasil Pekerjaan Siswa

Terlihat dari salah satu lembar jawaban siswa bahwa siswa tidak dapat menyelesaikan persoalan dengan benar yaitu pada indikator (1) siswa tidak dapat menuliskan model matematika dengan benar, (2) siswa tidak dapat menggambarkan grafik penyelesaian dari persoalan yang diberikan, (3) siswa tidak memahami permasalahan yang diberikan sehingga siswa tidak dapat menentukan menyelesaikan persoalan dengan benar. Selain itu, data secara keseluruhan dari soal yang dikerjakan siswa diperoleh (1) Pada soal nomor (1a) yaitu dari 30 orang siswa, yang mampu menyelesaikan soal dengan benar hanya ada 6 orang atau $20 \%$ dan 24 orang atau $80 \%$ menjawab dengan hasil salah. Disini menunjukan bahwa ketercapaian indikator ekspresi matematika/expression mathematical tergolong rendah. Pada indikator ini diharapkan siswa mampu menuliskan model matematika dengan benar, (2) Pada soal nomor (1b) yaitu dari 30 orang siswa, yang mampu menyelesaikan soal dengan benar hanya 2 orang atau $6,67 \%$ dan 28 orang atau 93,33\% menjawab dengan hasil salah. Disini menunjukan bahwa ketercapaian indikator menggambar/expression tergolong rendah. Pada indikator ini diharapkan siswa mampu menggambarkan grafik penyelesaian dari persoalan yang diberikan dengan benar, (3) Pada 
soal nomor (1c) yaitu dari 30 orang siswa, yang mampu menyelesaikan soal dengan benar hanya 6 orang atau $20 \%$ dan 24 orang atau sekitar $80 \%$ menjawab dengan hasil salah. Disini menunjukan bahwa ketercapaian indikator menulis/written texts tergolong rendah. Pada indikator ini diharapkan siswa mampu menyelesaikan persoalan yang diberikan dengan benar.Berdasarkan hasil prariset tersebut dapat disimpulkan bahwa kemampuan komunikasi matematis siswa kelas X MIPA SMA Negeri 1 Singkawang masih rendah.

Hal ini sejalan dengan hasil penelitian Fitriani (2013) tingkat kemampuan komunikasi matematis siswa berada pada kategori rendah. Hal ini terlihat pada kemampuan siswa dalam menggunakan simbol matematika dan struktur-strukturnya untuk menyajikan ide matematika, dari 27 siswa yang menjawab soal yang menuntut mereka berkomunikasi secara tertulis hanya 12 orang siswa yang mampu menjawab soal dengan benar dan lengkap.

Selain itu, penyebab rendahnya kemampuan komunikasi siswa juga terlihat dari pengamatan langsung penulisterhadap proses pembelajaran guru matematika di kelas X SMA Negeri 1 Singkawang yaitu dalam proses pembelajaran guru yang lebih aktif dari awal pembelajaran, menjelaskan materi hingga akhir pembelajaran, yang mana proses pembelajaran yang dilakukan masih berpusat pada guru (teacher centered learning), bukan pada siswa (student centered learning). Rendahnya aktivitas siswa disebabkan siswa tidak mau bertanya ataupun menjawab pertanyaan yang diberikan oleh guru dan siswa cenderung kurang serius ketika pembelajaran berlangsung, dan masih ditemukan siswa yang sibuk memainkan handphone ketika guru sedang mengajar. Pembelajaran seperti ini, mengakibatkan siswa kurang aktif dan cenderung pasif, sehingga aktivitas belajar siswa rendah.Sejalan dengan hasil observasi yang dilakukan Lesi, dkk (2015:2) di kelas X MIA SMAN 4 Pontianak menunjukan bahwa aktivitas siswa belum optimal, yang mana saat pengamatan didapat dari 38 siswa ada 20 orang siswa yang tidak memperhatikan dan 18 orang yang tidak menulis materi yang guru jelaskan.

Hal ini diperkuat dengan hasil observasi aktivitas siswa di kelas X MIPA 4 SMA Negeri 1 Singkawang yang terdiri dari 30 siswa. Hasil observasi aktivitas siswa diperoleh data bahwa aktivitas siswa yang memiliki persentase terendah berdasarkan jenis-jenis aktivitas dalam belajar yang digolongkan oleh Paul B. Diedric (Sardiman, 2014:101) yaitu oral activities terdapat 3 orang atau 10\% yang mengajukan pertanyaan pada saat pembelajaran berlangsung, listening activities terdapat 12 orang atau $40 \%$ yang mendengarkan penjelasan guru, visual activities terdapat 12 orang atau $40 \%$ yang memperhatikan pembelajaran yang disampaikan guru, dan emotional activities terdapat 9 orang atau 30\% yang bersemangat atau menaruh minat untuk mengikuti pembelajaran. Berdasarkan hasil pengamatan aktivitas siswa dapat disimpulkan bahwa aktivitas siswa kelas X MIPA SMA Negeri 1 Singkawang masih dalam kategori tidak aktif.

Selain observasi kelas mengenai aktivitas siswa penulis juga memberikan angket kemandirian belajar siswa terhadap pembelajaran matematika. Dari hasil pemberian angket kemandirian belajar siswa yang dilakukan penulis diperoleh data kemandirian belajar siswa terhadap pembelajaran yang dilakukan oleh guru di kelas X MIPA 4, dapat dilihat pada Tabel 1. 


\section{Tabel 1. Kemandirian Belajar Siswa terhadap Model Pembelajaran Langsung yang} Dilakukan Guru Matematika Di Kelas X MIPA 4.

\begin{tabular}{|c|c|}
\hline Kriteria Kemandirian Belajar Siswa & Total skor \\
\hline $\begin{array}{l}\text { Mengerjakan latihan soal dengan mandiri tanpa melihat } \\
\text { jawaban dari teman }\end{array}$ & 55 \\
\hline $\begin{array}{l}\text { Mengumpulkan tugas tepat waktu tanpa harus diperintah oleh } \\
\text { guru }\end{array}$ & 57 \\
\hline Menjawab pertanyaan dengan percaya diri & 45 \\
\hline Bersemangat saat mempresentasikan hasil pekerjaannya & 50 \\
\hline Jumlah Total Skor & 207 \\
\hline Nilai Rata-Rata & 6,9 \\
\hline Kriteria & $\begin{array}{l}\text { Sangat Kurang } \\
\text { Baik }\end{array}$ \\
\hline
\end{tabular}

Dari Tabel 1 kemandirian belajar siswa terhadap pembelajaran langsung hanya memperoleh nilai ratarata sebesar 6,9 dalam kriteria sangat kurang baik. Jika hal ini tidak segera diatasi maka tujuan pembelajaran matematika tidak tercapai.

Berdasarkan beberapa uraian permasalahan di atas tentulah diperlukan tindakan yang tepat untuk mengatasinya. Tindakan yang dapat dilakukan antara lain adalah dengan menerapkan berbagai model pembelajaran yang tentunya sesuai dengan tujuan yang ingin dicapai. Satu diantara model pembelajaran yang dapat diterapkan adalah model pembelajaran Student Facilitator and Explaining. Model pembelajaran Student Facilitator and Explaining adalah rangkaian penyajian materi ajar yang diawali dengan penjelasan secara terbuka, memberi kesempatan kepada siswa untuk mempresentasikan ide atau pendapat pada rekan peserta lainnya dan diakhiri dengan penyampaian semua materi kepada siswa (Huda, 2013:228). Melalui model pembelajaran Student Facilitator and Explaining siswa diajak untuk dapat menerangkan kepada siswa lain, siswa dapat mengeluarkan ideide yang ada dipikirannya sehingga lebih dapat memahami materi yang diberikan.

Model pembelajaran Student Facilitator and Explaining dapat melatih siswa untuk mampu berkomunikasi dengan diberikan kesempatan kepada siswa sebagai fasilitator dalam pembelajaran dan dapat memacu siswa agar lebih aktif serta mandiri dalam belajar. Sejalan dengan hasil penelitian Mufrika (2011:58) yang menunjukan bahwa rata-rata kemampuan komunikasi matematika siswa yang diajarkan menggunakan metode Student Facilitator and Explaining sebesar 66,5 lebih tinggi dan signifikan daripada rata-rata kemampuan komunikasi matematika siswa yang diajarkan menggunakan metode konvensional sebesar 59,13. Selain itu, model pembelajaran Student Facilitator and Explaining belum pernah diterapkan di SMA Negeri 1 Singkawang. Dengan demikian Student Facilitator and Explaining dapat dilakukan untuk mengatasi masalah pembelajaran siswa dalam upaya meningkatkan kemampuan komunikasi matematis siswa SMA Negeri 1 Singkawang.

Berdasarkan permasalahan yang telah dipaparkan secara umum diatas maka peneliti tertarik memilih penelitian dengan judul" Pengaruh Model Pembelajaran Student Facilitator and Explaining Terhadap Kemampuan Komunikasi Matematis Siswa Pada Materi SPLTV Kelas X MIPA”.

\section{METODE PENELITIAN}

Jenis penelitian yang digunakan ini adalah penelitian kuantitatif. Desain penelitian yang digunakan dalam penelitian ini adalah Quasi Experimental Design dengan rancangan Posttest-Only Control Design (Sugiyono, 2015:114). Penelitian dilaksanakan di SMA Negeri 1 Singkawang yang beralamat di Jalan Pahlawan gg. Tama Kelurahan Roban Kecamatan Singkawang Tengah. Adapun waktu pelaksanaan penelitian akan direncanakan pada semester ganjil tahun ajaran 2018/2019. Populasi 
dalam penelitian ini adalah siswa kelas X MIPA SMA Negeri 1 Singkawang yang terdiri dari 4 kelas dengan jumlah siswa sebanyak 125 yaitu kelas X MIPA 1, X MIPA 2, X MIPA 3, dan X MIPA 4. Teknik yang digunakan untuk mengambil sampel pada penelitian ini adalah teknik Purposive sampling. Adapun yang menjadi kelas eksperimen adalah kelas X MIPA 2 dan kelas kontrol adalah kelas X MIPA 4.Teknik pengumpulan data yang digunakan dalam penelitian ini adalah teknik pengukuran,teknik observasi langsung, dan teknik komunikasi tidak langsung. Teknik pengukuran yang dimaksud dalam penelitian ini adalah dengan menggunakan tes yang berbentuk uraian (essay) sebanyak 2 soal dalam materi sistem persamaan linier tiga variabel di kelas X MIPA SMA Negeri 1 Singkawang. Teknik observasi langsung dilakukan untuk mengetahui aktivitas belajar siswa dengan menerapkan model pembelajaran Student Facilitator and Explaining selama proses pembelajaran pada materi sistem persamaan linier tiga variabel.Pengamatan dilakukan oleh satu orang guru matematika dan satu orang mahasiswa. Teknik komunikasi tidak langsung dalam penelitian ini digunakan untuk mengetahui kemandirian dalam belajar dengan perlakuan, dalam hal ini digunakan angket kemandirian belajar.

Instrumen pengumpulan data dalam penelitian ini berupa soal tes kemampuan komunikasi matematis, lembar observasi aktivitas belajar, dan angket kemandirian belajar. Instrumen pengumpulan data berupa tes komunikasi terlebih dulu di uji validitas, reliabilitas, daya pembeda dan tingkat kesukarannya.Validitas bertujuan agar tes yang digunakan benar-benar untuk mengukur kemampuan siswa dalam menyelesaikan soal SPLTV, maka instrumen yang telah disusun diukur dengan validitas tes. Dari hasil perhitungan ketiga validator dengan aspek yang dinilai validitas RPP , soal posttest, lembar observasi aktivitas belajar, dan angket kemandirian belajar diperoleh kriterianya valid. Berdasarkan enam soal yang digunakan untuk menguji kemampuan komunikasi matematis siswa nomor soal 1a dan $2 \mathrm{c}$ dalam kategori tinggi, dan soal nomor $1 \mathrm{~b}, 1 \mathrm{c}, 2 \mathrm{a}, 2 \mathrm{~b}$ dalam kategori sedang, sehingga dapat diartikan bahwa soal kemampuan komunikasi layak digunakan. Berdasarkan hasil uji coba soal yang dilakukan peneliti di SMA Negeri 3 Singkawang dengan jumlah siswa 30 orang, secara keseluruhan tes kemampuan komunikasi matematis siswa yaitu sebesar $r_{11}=0,57$ yang berada pada kisaran diantara $0,40<0,57 \leq$ 0,60. Maka dapat diinterpretasikan bahwa soal tes kemampuan komunikasi matematis siswa tersebut termasuk dalam kategori sedang. Oleh karena itu, instrumen soal dikatakan reliabel, artinya soal tersebut ajeg atau kekonsinten digunakan untuk tes kemampuan komunikasi matematis siswa pada subjek yang sama pada waktu yang berbeda maka hasilnya akan relatif sama. Untuk indeks kesukaran soal tes kemampuan komunikasi matematis siswa yang terdiri dari 6 soal, menunjukan soal tes kemampuan komunikasi matematis siswa memiliki indeks kesukaran sedang. Maka soal tersebut layak untuk digunakan. Adapun hasil perhitungan daya dapat dilihat bahwa soal tes kemampuan komunikasi matematis siswa yang terdiri dari 6 soal, maka secara keseluruhan soal tes kemampuan komunikasi matematis siswa mempunyai memiliki daya pembeda 0,43 dengan kriteria baik. Artinya soal tersebut dapat digunakan untuk mengukur kemampuan komunikasi matematis siswa. Adapun rekapitulasi hasil uji coba soal kemampuan komunikasi matematis siswa setelah diuji validitas, reliabilitas, indeks kesukaran, dan daya pembeda maka dapat disimpulkan bahwa soal tersebut layak dipakai sebagai acuan untuk mengukur kemampuan komunikasi matematis siswa.

\section{HASIL DAN PEMBAHASAN}

Hasil pengumpulan data selama penelitian diperoleh data posttest kelas X MIPA 2 yang berjumlah 30 siswa sebagai kelas eksperimen yang diberikan model pembelajaan Student Facilitator and Explaining dan model pembelajaran konvensional kelas X MIPA 4 yang berjumlah 30 siswa sebagai kelas kontrol yang diberikan oleh guru matematika sekolah dengan model pembelajaran langsung terhadap kemampuan komunikasi matematis siswa pada materi SPLTV dan mengetahui adanya pengaruh kemampuan komunikasi matematis siswa kelas eksperimen dan kontrol. Pada kelas eksperimen yang menggunakan model pembelajaan Student Facilitator and Explaining terhadap kemampuan 
komunikasi matematis siswa tinggi dari pada kemampuan komunikasi matematis siswadi kelas kontrol yang menggunakan pembelajaran konvensional. Perbedaan peningkatan kemampuan komunikasi matematis siswa tersebut disebabkan adanya perbedaan yang ditimbulkan oleh masing-masing perlakuan dalam pembelajaran. Perbedaan kemampuan komunikasi matematis siswa yang lebih tinggi sebesar 70,37\% pada kelas eksperimen yang menggunakan model Student Facilitator and Explaining karena pada model pembelajaan Student Facilitator and Explaining tersebut dirancang untuk memberikan kesempatan kepada siswa untuk menjadi seorang pengajar/penjelas materi dan memfasilitasi proses pembelajaran antar siswa sesuai dengan materi, menciptakan lingkungan belajar yang kondusif dan menyenangkan serta menciptakan situasi pembelajaran yang aktif dan bermakna bagi siswa. Sedangkan belajar dengan menggunakan model pembelajaran konvensional dalam proses pembelajaran hanya berpusat kepada guru sehingga kurangnya interaksi antar siswa dan guru, dengan demikian siswa merasa bosan dalam mengikuti proses pembelajaran dan malas untuk bertanya jika belum mengerti sehingga masih banyak siswa yang mengalami kesulitan dalam mengerjakan soal yang sesuai dengan indikator kemampuan komunikasi matematis.

Kemampuan komunikasi matematis siswa dalam penelitian ini membahas 3 indikator yang terdiri (1)mathematical expression yaitu mengekspresikan konsep matematika dengan menyatakan peristiwa sehari - hari dalam bahasa atau simbol metematika; (2) drawing yaitu menyatakan suatu situasi dalam bentuk tabel; (3)written text yaitu memberi jawaban dengan menggunakan bahasa sendiri. Dari ketiga indikator komunikasi matematis siswa yang digunakan sebagai acuan untuk analisis indikator kemampuan komunikasi matematis siswa yang dilakukan diperoleh rata - rata keseluruhan nilai posttest kelas eksperimen sebesar 69,2 dan nilai posttest kelas kontrol sebesar 50,7. Hal ini menunjukan bahwa pembelajaran dengan menggunakan model pembelajaran Student Facilitator and Explaining yang diberikan pada kelas eksperimen lebih baik daripada pembelajaran dengan menggunakan model pembelajaran konvensional yang diberikan pada kelas kontrol. Hal ini terbukti pada pengujian hipotesis dengan menggunakan uji t dua sampel independen dengan membandingkan nilai $t_{\text {hitung }}$ dengan $t_{\text {tabel }}$ pada hasil posttest kemudian diperoleh $t_{\text {hitung }} \geq t_{\text {tabel }}(5,69 \geq 1,761)$ yang berarti Ho ditolak dan Ha diterima. Hal ini berarti terdapat perbedaan peningkatkan kemampuan komunikasi matematis siswa antara kelas eksperimen dan kelas kontrol pada materi SPLTV kelas X MIPA SMA Negeri 1 Singkawang. Sedangkan untuk pengujian besar pengaruh model pembelajaran Student Facilitator and Explaining terhadap kemampuan komunikasi matematis pada materi SPLTV dilakukan pengujian dengan menggunakan Effect Size, diperoleh bahwa nilai ES (effect size)sebesar 1,42. Hal ini menunjukan bahwa pengaruh variabel yang diteliti pada kelas eksperimen lebih besar dari kelas kontrol sehingga besar pengaruh model pembelajaran Student Facilitator and Explaining tergolong dalam kategori tinggi. Hal ini sejalan dengan penelitian yang dilakukan oleh Mufrika (2011) yang menyimpulkan bahwa penggunaan model pembelajaran Student Facilitator and Explaining dapat meningkatkan kemampuan komunikasi matematis siswa. Sehingga dapat disimpulkan bahwa terdapat pengaruh kemampuan komunikasi matematis siswa yang signifkan siswa yang diberikan model pembelajaran Student Facilitator and Explaining atau siswa yang diberikan model pembelajaran Student Facilitator and Explaining lebih baik daripada siswa yang diberikan model pembelajaran konvensional. Pengamatan aktivitas belajar siswa dengan model pembelajaran Student Facilitator and Explaining dalam penelitian ini membahas 4 kategori yang terdiri dari (1) Oral Activities(2) Listening Activities (3) Visual Activities (4) Emotional Activities. Dari keempat kategori aktivitas belajar siswa yang ada digunakan sebagai acuan untuk membuat lembar observasi sehingga dari hasil analisis indikator aktivitas belajar siswa yang dilakukan diperoleh rata-rata persentase aktivitas belajar siswa pada pertemuan I sebesar 80,5\% pada kriteri aktif, demikian juga rata-rata persentase aktivitas belajar siswa pada pertemuan II sebesar $82 \%$ pada kriteri Aktif. Berikut disajikan grafik diagram. 


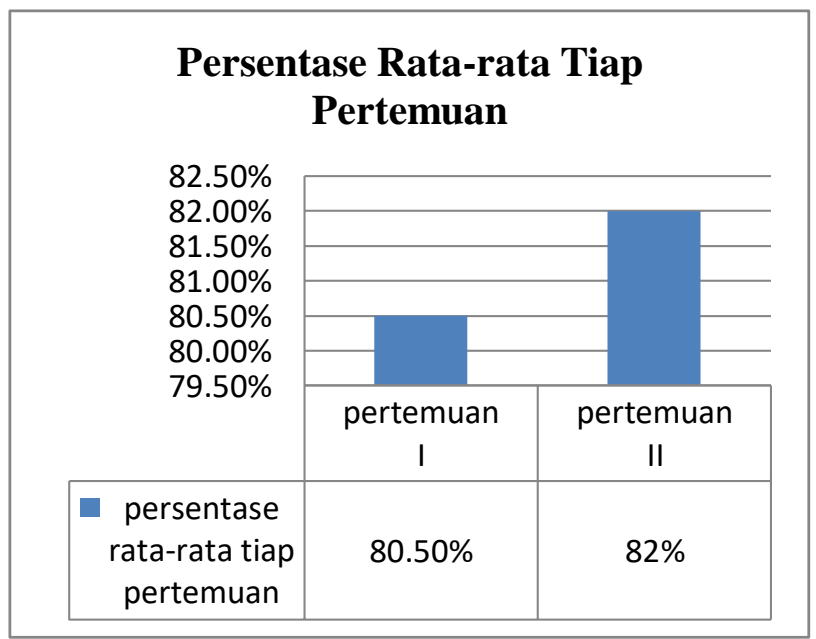

\section{Gambar 2. Grafik Persentase Rata-rata Aktivitas Pertemuan I dan Pertemuuan II}

Hasil ini sejalan dengan penelitian yang dilakukan oleh Prastyo (2010) yang menyimpulkan bahwa siswa menjadi aktif dengan menggunakan model pembelajaran Student Facilitator and Explaining. Hal ini menunjukan bahwa aktivitas belajar siswa dengan model pembelajaran Student Facilitator and Explaining di kelas X MIPA 2 SMA Negeri 1 Singkawang dikategorikan aktif.

Pada akhir pembelajaran dengan model pembelajaran Student Facilitator and Explaining, siswa diberikan lembar angket kemandirian belajar siswa untuk mengetahui seberapa besar kemandirian belajar siswa dalam mengikuti proses pembelajaran dengan model pembelajaran Student Facilitator and Explaining. Dalam penelitian ini angket kemandirian belajar digunakan dengan skala likert. Skala likert ini dibuat dalam bentuk checklist $(\sqrt{ })$ dengan memberikan jawaban atas pertanyaan sesuai pendapat siswa pada kolom yang telah disediakan pada angket kemandirian belajar. Kemudian siswa hanya dapat memilih satu pilihan dari lima alternatif jawaban yang diberikan yaitu Sangat Setuju (SS), Setuju (S), Ragu - ragu (RG), Tidak Setuju (TS), Sangat Tidak Setuju (STS). Dari hasil analisis data mengenai angket kemandirian belajar siswa diperoleh rata - rata angket kemandirian belajar siswa keseluruhan sebesar 44,73. Sesuai dengan kriteria penilaian angket kemandirian belajar siswa bahwa dengan rata-rata jumlah skor 44,73 berarti kemandirian belajar siswa pada kriteria baik. Dengan demikian dapat dikatakan bahwa sebagian besar siswa memiliki kemandirian belajar yang baik terhadap pembelajaran matematika menggunakan model pembelajaran Student Facilitator and Explaining terhadap kemampuan komunikasi matematis siswa pada materi SPLTV di kelas X MIPA 2 SMA Negeri 1 Singkawang.Hasil ini sejalan dengan penelitian yang dilakukan oleh Rizqi (2016) yang menyimpulkan bahwa kemandirian belajar siswa positif dengan menggunakan model pembelajaran Student Facilitator and Explaining. Hal ini menunjukan bahwa kemandirian belajar siswa dengan model pembelajaran Student Facilitator and Explaining di kelas X MIPA 2 SMA Negeri 1 Singkawang dikategorikan Baik.

\section{KESIMPULAN}

Berdasarkan hasil pengolahan data penelitian yang dilakukan, secara umum dapat disimpulkan bahwa model pembelajaran Student Facilitator and Explaining terhadap pengaruh kemampuan komunikasi matematis siswa pada materi sistem persamaan linier tiga variabel kelas XMIPA SMA Negeri 1 Singkawang. Sebagai fokus penelitian agar sejalan dengan sub-sub masalah penelitian yang telah ditentukan, hasil dari sub-sub masalah penelitian tersebut sebagai berikut:

1. Terdapat pengaruh model pembelajaran Student Facilitator and Explaining terhadap kemampuan komunikasi matematis siswa pada materi SPLTV kelas X MIPA SMA Negeri 1 Singkawang 
2. Siswa belajar dengan aktif setelah diberikan model pembelajaran Student Facilitator and Explaining pada materi SPLTV di kelas X MIPA SMA Negeri 1 Singkawang.

3. Kemandirian belajar siswa yang baik dengan model pembelajaran Student Facilitator and Explaining.

\section{DAFTAR PUSTAKA}

Buyung,B.,\& Nirawati, R. (2018). Pengaruh Karakter Kerja Keras Terhadap Kemampuan Literasi Matematis Siswa Melalui Model Discovery Learning. JPMI ( Jurnal Pendidikan Matematika Indonesia), 3 (1), 21-25.

Darkasyi, Muhammad. Dkk. (2014). Peningkatan Kemampuan Komunikasi Matematis Dan Motivasi Siswa Dengan Pembelajaran Pendekatan Kuantum Learning Pada Siswa

Negeri 5 Lhokseumawe. Jurnal Didaktik Matematika. ISSN: 2355-4185. Universitas Syiah Kuala, Banda Aceh.

Depdiknas. (2006). Peraturan Menteri Pendidikan Nasional Republik Indonesia tentang Standar Isi untuk Satuan Pendidikan Dasar dan Menengah. Jakarta:Depdiknas.

Fitriani, Dulis. (2013). Meningkatkan Kemampuan Komunikasi Matematik Siswa SMP dengan Pembelajaran Jakarta. Student Facilitator and Explaining. Jurnal Pendidikan Matematika,STKIP Siliwangi Bandung.

Huda, Miftahul. (2013). Model-Model Pengajaran dan Pembelajaran. Yogyakarta: Pustaka Pelajar.

Jazuli, Akhmad. (2009). Berfikir Kreatif dalam Kemampuan Komunikasi Matematika. Prosiding Seminar Nasional Matematika dan Pendidikan Matematika. FMIPA: UNY. ISSN: 978-97916353-3-2.

Lesi,dkk. (2015). Aktivitas Belajar Siswa pada Materi Struktur Atom Kelas X MIA Sekolah Menengah Atas Negeri 4 Pontianak. Jurnal Ilmiah, Universitas Muhammadiyah Pontianak.

Mufrika, Tika.(2011). Pengaruh Model Pembelajaran Kooperatif Dengan Metode Student Facilitator And Explaining (SFE) Terhadap Kemampuan Komunikasi Matematika Siswa Di Mts. Manaratul Islam Jakarta. Skripsi. UIN Syarif Hidayatullah.

Prastyo, Eko. (2010). Pengaruh Model Student Facilitator and Explaining terhadap aktivitas dan hasil belajar siswa materi invertebrate di SMA 1 Boja. Skripsi. Universitas Negeri Semarang.

Rizqi, Kartika Sari. (2016). Peningkatan Kemampuan Pemecahan Masalah Matematika dan Kemandirian Belajar melalui Penggunaan Model Pembelajaran Student Facilitator and Explaining di Sekolah Menengah Atas. Skripsi. Universitas Pasundan Bandung.

Rusman. (2012). Model-Model Pembelajaran. Jakarta: PT Raja Grafindo Persada.

Sardiman, A. M. (2014). Interaksi dan Motivasi Belajar Mengajar. Jakarta: PT Raja Grafindo Persada.

Sugiyono. (2015). Metode Penelitian Pendidikan. Bandung: CV Alfabeta.

Zainab. (2010). Komunikasi Matematis dalam Pembelajaran Matematika. Jurnal Guru. SMP Negeri 3 Pemulutan. 